\title{
Pengembangan Perangkat Pembelajaran Berbasis PBL Untuk Melatih Keterampilan Berpikir Kreatif Siswa
}

\author{
Syaiful Islami ${ }^{1,}$ Firrmansyah $^{2}$, Fitria Sarnita ${ }^{3}$ \\ STKIP Harapan Bima ${ }^{12}$ \\ STKIP Taman Siswa Bima ${ }^{3}$ \\ Email Coresspondent: syaifulislami.habi.ac.id
}

\begin{abstract}
(Development of PBL-Based Learning Tools to Train Students' Creative Thinking Skills). The background of this research is that a preliminary study has been carried out by the author, that the creative thinking ability of the students of SMPN 1 Ambalawi, Bima Regency is still lacking. This is because teachers do not train these skills and a more explicit learning model to train creative thinking skills is not applied. The aim of this research is a learning device with a student oriented PBL designs to train students' creative thinking. This research is developmental research. The framework of a quality product includes three criteria, namely validity, practicality, and effectiveness, this research was carried out at SMP Negeri 1 Ambalawi in class X.The results of Media Validation by both validates are on a scale of .46 with the Valid category. Material Validation is on a scale of 3.23 with the Valid category, while the results of the RPP Validation by the twovalidator are on a scale of 3.5 with the Valid category. Validation of BAS (Student Textbookby the twovalidator on a scale of 3.76 with a Very Valid category, the last Validation of student response questionnaires is on a scale of 3.55 with a Very Valid category. The results of the analysis of the increase in creative thinking skills on average for all students after participating in learning for eight meetings on the creative thinking aspect before treatment were $50.75 \%$ in the less creative category. Meanwhile, after being given treatment, it increased to $90.55 \%$ with the creative category, so that the average student responded positively to the proposed criteria, then the PBL-based learning device developed could be said to be feasible to use. The results of the research and discussion can be concluded that the development of PBL based learning tools developed is feasible to train students' creative thinking skills.
\end{abstract}

Keywords: Learning Tools, PBL, Creative Thinking.

\begin{abstract}
Abstrak
Latar belakang penelitian ini yakni telah dilakukan studi pendahuluan oleh penulis, bahwa kemampuan berpikir kreatif siswa SMPN 1 Ambalawi Kabupaten Bima masih kurang. Hal ini disebabkan karena Guru kurang melatihkan kemampuan tersebut dan model pembelajaran yang lebih eksplisit untuk melatih kemampuan berpikir kreatif tidak diterapkan. Tujuan dari penelitian ini perangkat pembelajaran dengan desain PBL yang berorientasi pada siswa untuk melatih berpikir kreatif siswa. Penelitian ini merupakan penelitian pengembangan (developmental research), Kerangka suatu produk yang berkualitas meliputi tiga kriteria,yaitu validity, practicality dan effectiveness, penelitian ini dilaksanakan di SMP Negeri 1 Ambalawi pada kelas X. Hasil Validasi Media oleh kedua validator berada pada skala 3,46 dengan kategori Valid. Validasi Materi pada skala 3,23 dengan kategori Valid, sedangkan hasil Validasi RPP oleh kedua validator berada pada skala 3,5 dengan kategori Valid. Validasi BAS (Buku Ajar Siswa) oleh kedua validator pada skala 3,76 dengan kategori Sangat Valid, Terakhir Validasi Angket respon siswa berada pada skala 3,55 dengan kategori Sangat Valid. Hasil analisis peningkatan keterampilan berpikir kreatif rata-rata seluruh siswa setelah mengikuti pembelajaran selama delapan pertemuan pada aspek berpikir kreatif sebelum perlakuan sebesar 50,75\% dengan kategori kurang kreatif. Sedangkan setelah diberikan perlakuan meningkat menjadi 90,55\% dengan kategori kreatif, sehingga diperoleh rata-rata siswa merespon positif terhadap kriteria-kriteria yang diajukan, maka perangkat pembelajaran berbasis PBL yang di kembangkan dapat dikatakan layak untuk digunakan. Hasil penelitian dan pembahasan dapat disimpulkan bahwa pengembangan perangkat pembelajaran berbasis PBL yang dikembangkan layak untuk melatihkan keterampilan berpikir kreatif siswa.
\end{abstract}

Kata Kunci: Perangkat Pembelajaran, PBL, Berpikir Kreatif

\section{PENDAHULUAN}

Indonesia adalah salah satu Negara yang berkembang, berbagai sarana dan prasarana mulai diperbaiki, seperti sektor ekonomi, pertahanan serta sektor pendidikan. Terbukti dalam rentang beberapa tahun saja telah terjadi beberapa kali pergantian kurikulum pendidikan Nasional, dan kita harus percaya bahwa pergantian kurikulum merupakan bagian dari transformasi pendidikan. Ada tiga hal yang perlu disoroti dalam konteks peningkatan mutu pendidikan: yaitu masalah kurikulum, 
peningkatan kualitas pembelajaran, dan efektivitas metode. Jika ingin hasil belajar yang berkualitas maka dalam proses pembelajaran haruslah berkualitas pula ${ }^{[1]}$. Guru sebagai perancang dan pengelola proses pembelajaran haruslah mendesain pembelajaran yang efektif dan efisien untuk siswa. Guru tidak hanya sebagai sumber informasi utama bagi siswanya, juga sebagai perancang dan pengembang perangkat pembelajaran, menentukan metode apa yang paling efektif dan efisien untuk mengajarkan konsep ${ }^{[2]}$.Siswa akan menemukan dan membangun pengetahuannya sendiri dari berbagai sumber belajar yang tidak lagi dibatasi oleh dinding kelas kemudian menggunakan bangunan pengetahuannya untuk memecahkan permasalahan dalam kehidupan nyata ${ }^{[3]}$.

Teori perkembangan Piaget berpandangan tentang perkembangan kognisi sebagai proses anak secara aktif membangun sistem pengertian dan pemahaman tentang realitas melalui pengalaman dan interaksi mereka $^{[4]}$. Maka proses belajar mengajar haruslah bertujuan untuk mempersiapkan manusia Indonesia sebagai pribadi yang produktif, kreatif dan inovatif. Oleh karena itu, pembelajaran hendaknya memfokuskan pada proses transformasi dan tidak sekedar mentransfer pengetahuan begitu saja ${ }^{[5]}$. Guru dapat menggabungkan pengajaran dan pengalaman diruang kelas sehari-hari untuk menciptakan budaya berpikir sedang budaya berpikir adalah bagian dari pengajaran berpikir [4]. Salah satu kecakapan hidup (life skill) yang perlu dikembangkan melalui proses pendidikan adalah keterampilan berpikir ${ }^{[6]}$.Guru harus mengembangkan keterampilan berpikir siswa dengan menyajikan fenomena sains yang otentik, sehingga siswa bisa memunculkan banyak ide-ide atau alternatif dalam menyelesaikan masalah.Sedangkan menurut Maslow $^{[7]}$ berpikir kreatif merupakan manifestasi dari individu yang berfungsi sepenuhnya.Maka dipandang perlu mencari model-model pembelajaran yang sesuai dengan kondisi siswa, materi dan tujuan pembelajaran. Salah satunya adalah model pembelajaran Problem Based Learning (PBL).

Telah dilakukan studi pendahuluan oleh penulis, bahwa kemampuan berpikir kreatif siswa SMPN 1 Ambalawi Kabupaten Bima masih kurang. Hal ini disebabkan karena Guru kurang melatihkan kemampuan tersebut dan model pembelajaran yang lebih eksplisit untuk melatih kemampuan berpikir kreatif tidak diterapkan. Dari deskripsi di atas dipandang perlu bagi peneliti untuk mengembangkan perangkat pembelajaran IPA model Inkuiri Terbimbing untuk melatih keterampilan berpikir kreatif siswa SMPN 1 Ambalawi. Tujuan penelitian ini secara umum adalah menghasilkan perangkat pembelajaran IPA model Problem Based Learning (PBL) yang layak untuk melatih keterampilan berpikir kreatif siswa.

Penelitian tentang keterampilan berpikir kreatif sudah banyak dilakukan oleh para peneliti dengan berbagai metode yang ada $[3,4,6,8]$. Beberapa penelitian yang sudah peneliti lakukan, yang berkaitan dengan inovasi terhadap penelitian keterampilan berpikir kreatif dengan menggunakan model pembelajaran berbasis masalah [1,6,18]. Berdasarkan penelitian yang sudah dilakukan yang telah diuraikan maka keterbaruan pada penelitian ini adalah perangkat pembelajaran dengan desain PBL yang berorientasi pada siswa untuk melatih berpikir kreatif siswa. Sehingga siswa mampu menyelesaikan berbagai permasalahan hidup baik di sekolah maupun di masyarakat.

\section{METODE}

Penelitian ini merupakan penelitian pengembangan (developmental research), Kerangka suatu produk yang berkualitas meliputi tiga kriteria,yaitu validity, practicality and effectiveness. karena penelitian mengembangkan perangkat pembelajaran yang meliputi silabus, Rencana Pelaksanaan Pembelajaran (RPP), Lembar Kerja Siswa (LKS), Buku Ajar Siswa (BAS) dan Instrumen Berpikir Kreatif. Perangkat yang telah selesai dikembangkan selanjutnya akan diimplementasikan di kelas ${ }^{[19]}$. Penelitian dilaksanakan di kelas VII semester 2 SMPN Ambalawi Kabupaten Bima NTB pada Tahun pelajaran 20120/2021, kelas X dengan jumlah siswa 36 siswa. Penelitian ini menggunakan model 4D (four $D$ models) yang terdiri dari empat tahap, yaitu tahap pendefinisian (define), 
perancangan (desain), pengembangan (develop) dan penyebaran (disseminate).

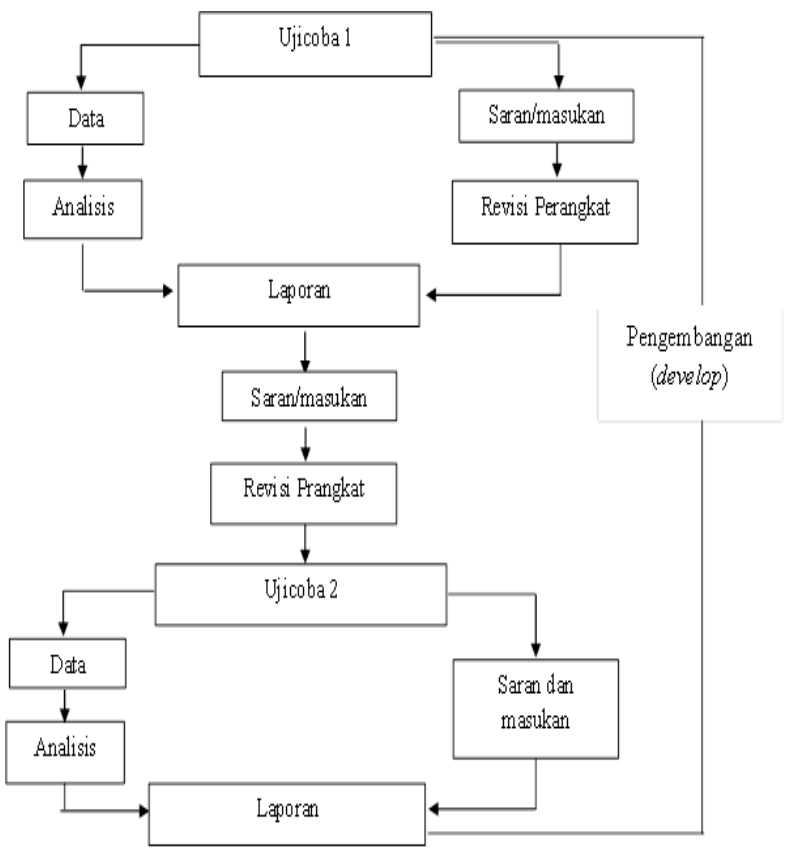

Gambar 1. Alur bagan penelitian.

\section{HASIL DAN PEMBAHASAN}

a. Validasi perangkat pembelajaran berbasis PBL untuk melatih keterampilan berpikir kreatif siswa.

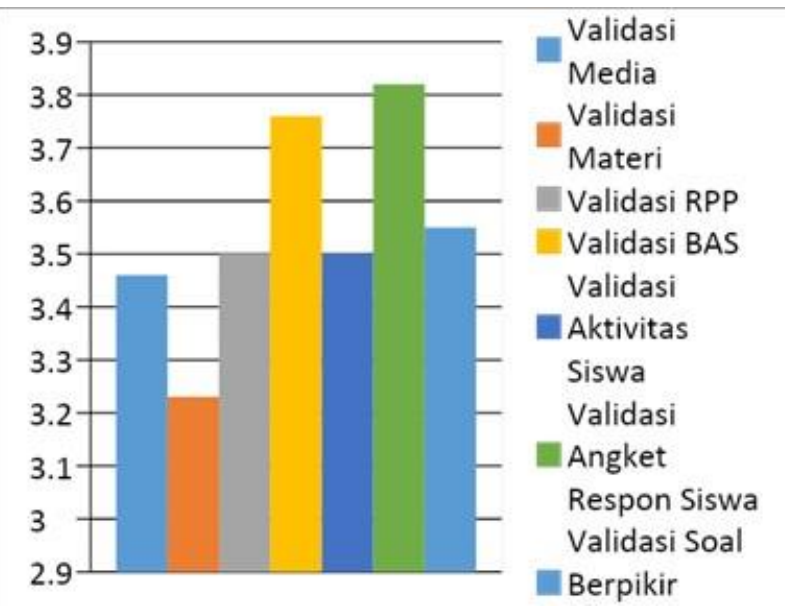

Grafik 1. Validasi Perangkat Pembelajaran.

Hasil Validasi Media oleh kedua validator yang terdiri dari penilaian kelayakan isi media, penyajian media, bahasa yang digunakan pada media, gambar yang digunakan dalam media maka hasil validasi berada pada skala 3,46 dengan kategori Valid. Selanjutnya Validasi Materi indikator yang dinilai terdiri dari kebenaran substansi materi, pemilihan materi yang sesuai dengan sumber belajar, manfaat untuk menambah wawasan, Kejelasan informasi, pemilihan materi pembelajaran sesuai dengan perkembangan zaman, maka hasil validasi berada pada skala 3,23 dengan kategori Valid. Sedangkan Validasi RPP oleh kedua validator yang terdiri dari penilaian kelayakan isi RPP, penyajian RPP, bahasa yang digunakan pada RPP, gambar yang digunakan dalam RPP maka hasil validasi berada pada skala 3,5 dengan kategori Valid. Untuk Validasi BAS (Buku Ajar Siswa) oleh kedua validator yang terdiri dari penilaian kelayakan isi BAS, penyajian BAS, bahasa yang digunakan pada RPP, gambar yang digunakan dalam BAS maka hasil validasi berada pada skala 3,76 dengan kategori Sangat Valid. Terakhir Validasi Angket respon siswa berada pada skala 3,55 dengan kategori Sangat Valid.

RPP, LKS, Instrumen dan jenis perangkat pembelajaran lainnya baru bias digunakan jika persentase kecocokan antara validator $\geq 75 \%$ (Borich, 1994) dalam Sarnita 2019 . Persentase kecocokan dari masingmasing perangkat yang telah dibuat rata-rata $\geq$ $75 \%$. Sedangkan Percentage Of Agreement (R) atau persentase kecocokan kedua validator untuk Media adalah 86,6, Materi adalah 80,2. V. RPP adalah 87,8. BAS adalah 88,5, Lembar Aktivitas Siswa adalah 86,3, Respon Siswa adalah 85,7 untuk soal berpikir kreatif siswa adalah 87,9. maka perangkat pembelajaran berbasis PBL yang dikembangkan dapat digunakan untuk dilakukan uji coba pada siswa.

b. Kepraktisan perangkat pembelajaran Berbasis PBL untuk melatih keterampilan berpikir kreatif siswa.

Perangkat pembelajaran yang dikembangkan dikatakan praktis apabila RPP terlaksana dengan baik tanpa ada hambatan serta mendukung aktivitas siswa sesuai dengan tujuan pembelajaran yaitu melatih siswa berpikir kreatif berbasis PBL. Pengamatan dilakukan selama 8 kali pertemuan oleh dua orang pengamat, hasil analisis dari semua kegiatan yang ada di dalam RPP dengan skor rata-rata adalah 3,41 dengan kategori baik. Dapat dilihat pada grafik dibawah ini : 


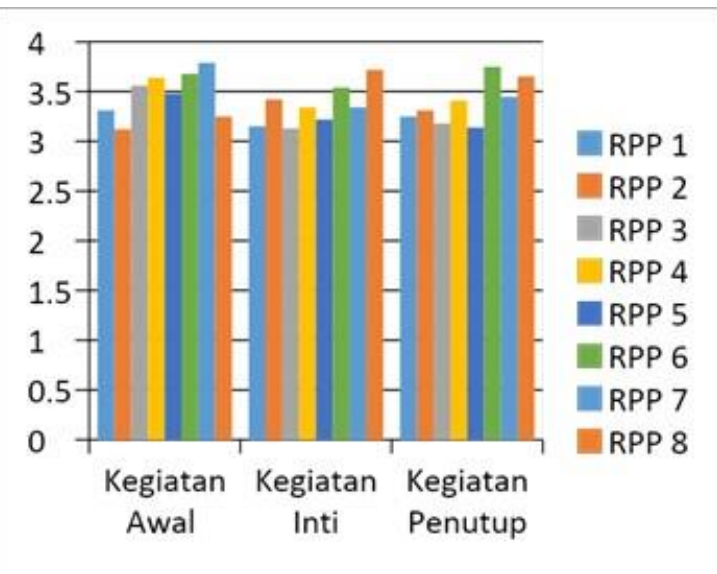

Grafik 2. Keterlaksanaan Rencana PelaksanaanPembelajaran.

Hasil pengamatan untuk aktivitas siswa dapat diketahui dari pertemuan 1-8. Hal ini terbukti dari peningkatan aktivitas siswa yang signifikan dari pertemuan pertama sampai pertemuan terakhir. Pada pertemuan pertama hanya $50 \%$ siswa yang aktif dan memberikan kontribusi positif, namun di akhir pertemuan meningkat menjadi $90 \%$ siswa. Keterlibatan siswa secara aktif dalam pembelajaran membuatnya terlatih menemukan alternatif lain dalam menyelesaikan masalah yang ditemukan dalam pembelajaran. Hal ini senada dengan Vygotsky (dalam sarnita 2019) kecerdasan berkembang karena orang menghadapi pengalaman-pengalaman baru dan membingungkan kemudian berusaha menyelesaikan perbedaan dengan mengaitkan pengetahuan baru dengan pengetahuan awal dan membangun makna baru.

c. Keefektifan perangkat pembelajaran Berbasis PBL untuk melatih keterampilan berpikir kreatif siswa.

Perangkat pembelajaran yang dikembangkan dikatakan efektif apabila instrumen atau soal yang dibuat dapat mengukur apa yang diukur dan siswa memberikan respon positif terhadap model, metode, strategi atau perangkat yang telah kita kembangkan. Hasil analisis peningkatan keterampilan berpikir kreatif rata-rata seluruh siswa setelah mengikuti pembelajaran selama delapan pertemuan pada aspek berpikir kreatif sebelum perlakuan sebesar 50,75\% dengan kategori kurang kreatif. Sedangkan setelah diberikan perlakuan meningkat menjadi 90,55\% dengan kategori kreatif.

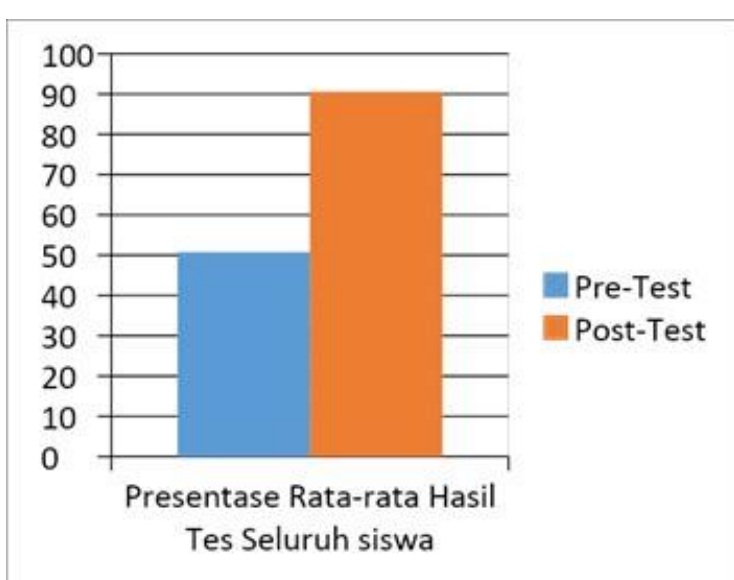

Grafik 3. Hasil Tes Berpikir Kreatif Siswa.

Perangkat pembelajaran yang telah dikembangkan bertujuan untuk memberikan kontribusi kepada peningkatan berpikir kreatif siswa. Seperti pada BAS yang telah dirancang berbasis PBL memberikan ruang kepada siswa untuk melakukan percobaan, terlibat secara aktif dalam proses belajar, menyampaikan ide sebanyak mungkin, mencoba sesuatu yang baru. Nur M., (2014) menjelaskan bahwa satu-satunya cara agar orang dapat mempelajari teknik-teknik dalam melakukan penemuan adalah ia memiliki kesempatan untuk melakukan penemuan. Tes berpikir kreatif ini bertujuan untuk mengetahui sejauh mana tingkatan berpikir kreatif yang dimiliki oleh siswa, karena tidak ada jaminan bahwa siswa yang pintar bisa dikatakan siswa yang kreatif. Esensi dari tes keterampilan berpikir kreatif adalah untuk melatih bagaimana keluasan dan imajinasi orang dalam menganalisis masalah (Adams, 2005).

Sehingga diharapkan ketika siswa mampu menyelesaikan masalah di sekolah dengan unsur unsur kreatif, maka siswa tersebut juga dapat menyelesaikan masalah dalam kehidupannya sehari-hari. Sedangkan hasil analisis respon siswa selama proses pembelajaran dan pada perangkat yang dikembangkan diperoleh rata-rata siswa merespon positif terhadap kriteria-kriteria yang diajukan. Sebanyak $100 \%$ dari seluruh responden merasa tertarik terhadap model pembelajaran dan perangkat yang gunakan, dan berharap supaya pada kegiatan pembelajaran berikutnya seperti yang mereka terima dapat diterapkan kembali. 


\section{KESIMPULAN}

Hasil penelitian dan pembahasan dapat disimpulkan bahwa pengembangan perangkat pembelajaran berbasis PBL yang dikembangkan layak untuk melatihkan keterampilan berpikir kreatif siswa.

\section{SARAN}

Penelitian ini dapat di kembangkan lagi terutama pada aspek elaborasi untuk berpikir kreatif.

\section{UCAPAN TERIMA KASIH}

Terima kasih Tim peneliti ucapkan kepada KEMENRISTEK DIKTI BRIN yang telah mempercayakan penelitian ini dengan nomor kontrak :069/E4.1/AK.04.PT/2021 Indonesia yang telah membantu mendanai penelitian ini 100\%. Ketua STKIP Harapan Bima yang telah mengizinkan kami melakukan penelitian. Kepala Sekolah SMAN 1 Ambalawi dan guru IPA yang telah membantu proses penelitian dan semua pihak yang telah membantu dalam proses penelitian ini yang tidak dapat disebutkan satu per satu.

\section{DAFTAR PUSTAKA}

[1] Widia, Ibrahim M., \& Sucipto (2016) Pengaruh pendekatan Contextual Teaching and Learning (CTL) berbasis inkuiri terhadap hasil belajar siswa. Jurnal Ilmiah Pendidikan Fisika "Lensa" Vol. 2. No 2. Pp, 223-228.

[2] Slavin. (2016). Psikologi pendidikan: teori dan praktik. (Alih Bahasa: Drs. Marianto Samosir). Jakarta: PT Indeks.

[3] Sulardi, dkk (2015), Pengembangan Perangkat Pembelajaran Fisika Model Problem Based Learning (PBL) untuk Melatih Keterampilan Berpikir Kritis Siswa.Jurnal Pendidikan Sains Pasca Unesa. Vol. 5. No. 1, pp. 802-810.

[4] Suryawati, E. W. \& Ardiyas R.S (2017) Kemampuan Berpikir Kreatif dan Penguasaan Konsep Siswa Melalui Model Problem Based Learning (PBL) dalam Pembelajaran Biologi Kelas XI IPA SMAN 2 Pekanbaru Tahun Ajaran 2010/2011. Jurnal Biogenesis, Vol. 8, No.1,pp. 1-7.
[5] Thagard at al. (2018).Creative Cognition in Social Innovation.Creativity Research Journal,Vol. 26 No.4, pp, 375-388.

[6] Satriawan M., Murtalib \& Widia (2018). Pengembangan Perangkat Pembelajaran Fisika Model Problem Based Learning (PBL) berbasis Karakter Maja labo Dahu untuk Melatih Keterampilan Berpikir Kreatif Siswa. Gravity Edu: Jurnal Pembelajaran dan Pengajaran Fisika. Vol. 01 No 02. Pp 20-24

[7] Trianto.(2007). Model-Model Pembelajaran Inovatif Berorientasi Konstruktivistik. Jakarta :Prestasi Pustaka.

[8] Wasis. (2015). Hasil Pembelajaran Sains Di Indonesia: Problem \& Upaya Mengatasinya. Makalah Utama Prosiding Seminar Nasional "Pembelajaran dan Penilaian Sains Sesuai Tuntutan Kurikulum 2013" Surabaya, 24 Januari 2015. ISBN: 978-602-72071-0-3.

[9] Rahmawati,. Soegimin, \& Soeparman Kardi, (2015) Pengembangan Perangkat Pembelajaran Fisika Model Inkuiri Terbimbing Berbantuan Videoscribe Pada Materi Kalor untuk Meningkatkan Hasil Belajar Siswa SMAN 1 Kedungwaru. Jurnal Penelitian Pendidikan Sains (JPPS) Pasca Unesa.Vol. 5. No 2. pp, 1039-1047.

[10] Satriawan, M. \& Rosmiati (2016). Pengembangan Bahan Ajar Fisika Berbasis Kontekstual Dengan Mengintegrasikan Kearifan Lokal Untuk Meningkatkan Pemahaman Konsep Fisika Pada Mahasiswa.Jurnal Penelitian Pendidikan Sains (JPPS).Vol.6 No.1 pp.1212 - 1217.

[11] Potur, A. A. \& Barkul, O. (2019). Gender and Creative thinking in Education: $A$ Theoretical and Experimental Overview. Vol. 6. No. 2: 46-57.

[12] Kemendikbud.(2013). Kurikulum 2013. Jakarta: Badan Penelitian dan Pengembangan.

[13] Khanafiyah, S \& Rusilowati, A.(2018). Penerapan Pendekatan Modified Free Inquiry sebagai Upaya Meningkatkan Kreativitas Mahasiswa Calon Guru dalam Mengembangkan Jenis Eksperimen dan 
Pemahaman Terhadap Materi Fisika. Jurnal Berkala Pendidikan, Universitas Negeri Semarang.Vol. 13. No. 2, pp 7-17.

[14] Dewi, F. (2016) "Proyek Buku Digital: Upaya Peningkatan Keterampilan Abad 21 Calon Guru Sekolah Dasar Melalui Model Pembelajaran Berbasis Proyek" Metodik Didaktik Vol.9, No. 2, pp. 1-15.

[15] Dennis, K. \& Filasaime,(2015).Menguak Rahasia berpikir Kritis dan Kreatif edisi revisi. Jakarta; Prestasi Pustakaraya.

[16] Dinata, Iskandar (2018) Merefleksi Nilai Budaya "Maja labo Dahu" dalam PEMDA. Kerukunan Keluarga Pelajar Mahasiswa Bima (KKPMB). Yogyakarta: Lengge Printika.

[17] Fisher, A. (2019). Critical Thinking An Introduction. X. Cambridge University Press.

[18] Satriawan M, Murtalib \& Widia (2018). Pengembangan Perangkat Pembelajaran Fisika Model Problem Based Learning (PBL) berbasis Karakter Maja labo Dahu untuk Melatih Keterampilan Berpikir Kreatif Siswa. Gravity Edu: Jurnal Pembelajaran dan Pengajaran Fisika. Vol. 01 No 02. Pp 20-24.

[19] Arends, R. (2018). Learning to Teach. Penerjemah: Helly Prajitno \& Sri Mulyani. New York:McGraw Hill Company.

[20] Adams K. (2005) The Sources of Innovation and Creativity. National Center on Education and the Economy (NCEE).

[21] Arends, R. I. (2012). Learning to Teach: Belajar untuk mengajar edisi Ketujuh Buku Satu. Yogyakarta: Pustaka Pelajar.

[22] Nur, M. (2014). Berpikir Kreatif. Surabaya: Penelitian Unggulan Perguruan Tinggi UNESA. 